194 Matrik : Jurnal Manajemen, Strategi Bisnis dan Kewirausahaan Vol. 13, No. 2, Agustus 2019

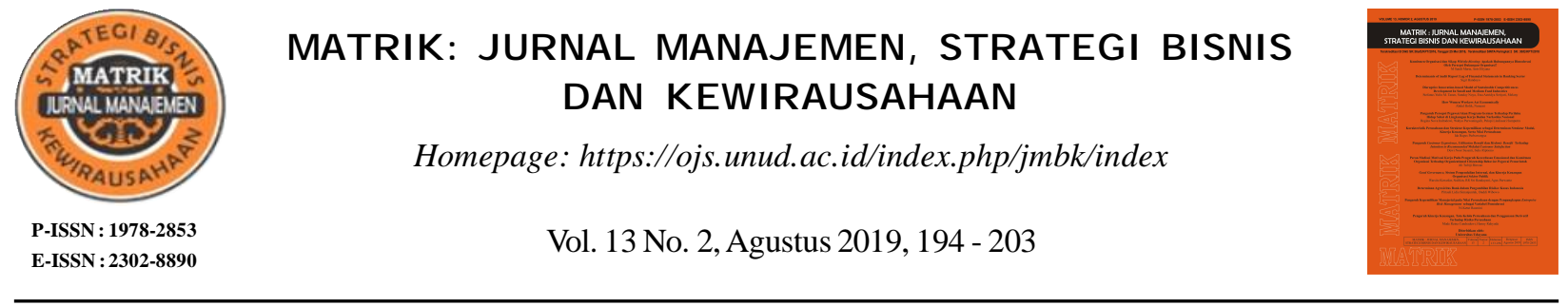

\title{
Pengaruh Customer Experience, Utilitarian Benefit dan Hedonic Benefit Terhadap Intention to Recommended Melalui Customer Satisfaction
}

\author{
Dewi Noor Susanti ${ }^{1)}$, Sulis Riptiono ${ }^{2)}$ \\ ${ }^{1)}$ Sekolah Tinggi Ilmu Ekonomi Putra Bangsa, Kebumen \\ ${ }^{2}$ Doktor Ilmu Manajemen Universitas Jenderal Soedirman, Purwokerto \\ email: sulis.riptiono@gmail.com
}

DOI : https://doi.org/10.24843/MATRIK:JMBK.2019.v13.i02.p07

\begin{abstract}
ABSTRAK
Pengalaman konsumen dan desain suatu produk merupakan salah satu unsur yang penting dalam pemasaran, manfaat desain diharapkan mampu membuat konsumen merasa puas. Apakah pengalaman konsumen dan design benefit selalu dapat meingkatkan kepuasan konsumen? Penelitian ini bertujuan untuk menguji pengaruh customer experience dan design benefit (utilitarian benefit dan hedonic benefit) terhadap intention to recommended dengan kepuasan konsumen sebagai variabel interviening. Penelitian yang dilakukan dengan dengan melibatkan 100 responden yang menggunakan produk smartphone iPhone di Kabupaten Kebumen, diambil dengan menggunakan tehnik purposive sampling. Data yang terkumpul kemudian dianalisis dengan menggunakan analisis jalur dan diolah dengan bantuan alat statistic SPSS 24.0. Hasil penelitian menunjukkan bahwa dari ketujuh hipotesis hanya ada satu yang ditolak yaitu hipotesis kelima. Temuan penelitian ini mengungkapkan bahwa variabel customer experience dan hedonic benefit merupakan anteseden dari kepuasan konsumen yang dapat menumbuhkan intention to recommended, sedangkan pada variabel utilitarian benefit hanya dapat berpengaruh terhadap kepuasan konsumen tetapi tidak dapat menumbuhkan intention to recommended konsumen.
\end{abstract}

Kata Kunci: costomer experience, customer satisfaction, hedonic benefit, utilitarian benefit, intention to recommended

The Influence of Customer Experience, Utilitarian Benefit and Hedonic Benefit on Intention to Recommended Through Customer Satisfaction

\begin{abstract}
Consumer experience and design product is one of the important elements in marketing, the benefits design are expected to be able to make consumers feel satisfied. Does the consumer experience and design benefits always increase customer satisfaction? This study aims to examine the effect of customer experience and design benefits (utilitarian benefit and hedonic benefits) toward intention to recommended with customer satisfaction as an interviening variable. Research conducted by involving 100 respondents using iPhone smartphone products in Kebumen City was taken using purposive sampling technique. The collected data and analyzed using path analyze and processed using the SPSS 24.0 statistical tool. The hypotheses result of the study show that from the seven hypotheses there is only one that is rejected, namely the fifth hypothesis. The findings of this study reveal that the customer experience and hedonic benefit variables are antecedents of consumer satisfaction that can foster the intention to be recommended, where as in the utilitarian variable benefits can only influence consumer satisfaction but cannot foster the intention to be recommended by consumers.
\end{abstract}

Keywords: costomer experience, customer satisfaction, hedonic benefit, utilitarian benefit, intention to recommended

\section{PENDAHULUAN}

Bisnis smartphone merupakan salah satu bisnis yang mengalami persaingan ketat pada industri teknologi dan komunikasi. Pada saat ini smartphone merupakan kebutuhan primer baru bagi manusia yang dapat memberikan berbagai manfaat bagi pengguna, yaitu manfaat utilitarian dan manfaat hedonis. Manfaat utilitarian dari smartphone 
mempunyai manfaat fungsional yang dihasilkan oleh kinerja produk yang berperan dalam mencapai hasil yang bernilai dan berbeda dari penggunaan itu sendiri, dan manfaat hedonis smartphone mempunyai manfaat non-fungsional yang dihasilkan oleh kinerja produk untuk mendapatkan kepuasan konsumen $(\mathrm{Xu}$ et al., 2015).

Kehadiran smartphone sendiri sebenarnya sudah ada sejak 1993 dan diedarkan terbatas di pasar. Smartphone pada saat itu hanya diperuntukkan bagi kalangan enterprise dan dibanderol dengan harga yang sangat mahal. Hal ini tidak dapat disangkal bahwa peluncuran iPhone dari Apple di tahun 2007 sangat menggemparkan dunia dan definisi smartphone langsung berubah menjadi mass consumer market serta dianggap sebagai salah satu inovasi ponsel terbesar yang pernah ada dengan mengusung sistem operasi iOS. Pada tahun 2017, Apple (2017) berhasil menjual produknya dengan total 216,76 juta iPhone. Model bisnis yang tepat dan pemasaran yang sukses adalah faktor kunci yang berkontribusi terhadap kesuksesan iPhone (Lee dan Kim, 2019).

Semakin banyak persaingan bisnis smartphone yang muncul akan membuat konsumen menjadi semakin kritis untuk mencari produk dengan fitur terbaik dari yang ditawarkan di pasaran. Google Android dan Apple iOS merupakan dua sistem operasi smartphone paling populer di industri. Pada tahun 2016, hampir 1,5 miliar smartphone dengan sistem operasi Android atau iOS dijual kepada pengguna akhir di seluruh dunia. Android, dengan $80 \%$ dari seluruh penjualan ponsel cerdas, memimpin pasar. Sebaliknya, sekitar 15\% dari semua ponsel pintar yang dijual ke pelanggan akhir memiliki iOS sebagai sistem operasinya (Lee dan kim, 2019). Meskipun demikian, iPhone dapat memenuhi tuntutan pelanggan mereka (Luagesen dan Yuan, 2010) karena iphone memberikan kepuasan tersendiri bagi konsumennya berdasarkan pengalaman konsumen dalam menjelajah internet seluler dan beragam aplikasi dari App Store (Lee dan Kim, 2019). Salah satu keunggulan yang ditawarkan iPhone adalah dengan performance dan desain produknya yang berkualitas sehingga membuat konsumen berniat untuk membeli serta memberikan dampak terhadap kepuasan pengguna iphone.

Selama beberapa dekade terakhir, kepuasan pelanggan telah menjadi modal penting bagi perusahaan dalam mengelola hubungan antara produk dan pelanggan mereka. Para peneliti menemukan bahwa tingkat kepuasan pelanggan yang tinggi tidak serta merta akan berdampak pada tingkat loyalitas pelanggan yang tinggi pula (Chitturi et al., 2008; Dewi dan Suprapti, 2018; Prayag et al., 2017). Produk harus dapat memberikan manfaat kepada pelanggan untuk mengarah pada loyalitas pelanggan (Smith dan Wright, 2004). Secara umum, semakin banyak manfaat yang ditawarkan kepada konsumen, semakin sukses suatu produk (Jang et al., 2005). Dengan demikian, perusahaan mencari keunggulan kompetitif dengan memberikan manfaat konsumen, sementara pelanggan memilih produk yang mereka anggap menawarkan manfaat terbaik (Fischer dan Frewer, 2009). Salah satu faktor penting yang dapat memberikan kontribusi pada keunggulan kompetitif dan diferensiasi produk adalah pengemasan (Rundh, 2009). Dengan demikian, pengemasan produk (penyajian eksterior suatu produk) hadir pada saat krusial ketika konsumen membuat keputusan pembelian (Ampuero dan Vila, 2006).

Pentingnya mengkomunikasikan manfaat produk membuatnya penting bagi pemasar untuk mengembangkan pemahaman yang lebih baik tentang desain kemasan (Löfgren, 2008). Kemasan produk untuk konsumen adalah dimensi penting dari citra produk, perusahaan menggunakan desain kemasan sebagai alat strategis untuk membedakan dan mengembangkan ekuitas produk mereka (Wang, 2017). Konsumen menggunakan berbagai isyarat untuk membentuk evaluasi keseluruhan kualitas produk (Krystallis dan Ness, 2003). Studi empiris mengungkapkan bahwa kemasan produk memberikan isyarat produk kepada konsumen, memberikan identifikasi merek, perbedaan visual (Underwood, 2003). Sudut pandang pengembangan produk mempertimbangkan desain kemasan sebagai alat pemasaran (Löfgren dan Witell, 2005) dan untuk komunikasi kepada konsumen (Silayoi dan Speece, 2007).

Meskipun kemasan produk mempunyai peranan yang penting dan sebagai faktor utama dalam penilaian pelanggan, beberapa literatur pemasaran mengungkapkan masih terbatas dalam memahami bagaimana kemasan termasuk desain yang mempengaruhi proses evaluasi konsumen (Orth et $a l ., 2010)$. Selain itu, ada masih sedikitnya penelitian serupa tentang bagaimana konsumen dapat menggunakan manfaat desain untuk menyimpulkan kualitas produk yang dirasakan dan mempengaruhi 
niat untuk merekomendasikan (Wang et al., 2017). Kebaruan dalam artikel ini adalah dengan memberikan tambahan variabel consumer experience serta menguji peran kepuasan sebagai anteseden dari niat konsumen untuk merekomendasikan. Berdasarkan beberapa hal tersebut diatas artikel ini bertujuan untuk menguji pengalaman konsumen dan dampak manfaat desain produk terhadap kepuasan dan dampaknya terhadap niat untuk merekomendasikan kepada orang lain dalam konteks produk dengan membandingkan berbagai manfaat (yaitu, utilitarian dan hedonis) studi pada konsumen iPhone di Kabupaten Kebumen.

Konsisten dengan penelitian sebelumnya dalam bidang pemasaran, kami akan menggunakan manfaat utilitarian untuk merujuk pada manfaat fungsional, instrumental, dan praktis dari penawaran konsumsi, dan hedonik untuk merujuk pada manfaat terkait estetika, pengalaman, dan kenikmatan (Chitturi et al., 2008; Wang et al., 2017). Chitturi et al. (2008) mengemukakan bahwa nilai konsumen merupakan pengalaman yang dihasilkan dari konsumsi manfaat tersebut. Studi dalam konteks ponsel, misalnya, masa pakai baterai dan volume suara ponsel adalah manfaat utilitarian, sementara daya tarik estetika dari bentuk dan warnanya adalah manfaat hedonis. Penelitian sebelumnya berfokus terutama pada penilaian bobot relatif yang dilampirkan konsumen pada dua dimensi ini dalam keputusan pra-konsumsi. Chitturi et al. (2007) mendokumentasikan bahwa konsumen lebih mementingkan dimensi hedonis daripada dimensi utilitarian), tetapi hanya setelah tingkat fungsionalitas yang perlu dipenuhi. Wang et al. (2017) mengemukakan bahwa konsumen lebih mementingkan dimensi utilitarian daripada manfaat hedonis, kecuali mereka merasa bahwa mereka telah mendapatkan hak untuk dituruti keinginannya.

Beberapa studi telah mengkonseptualisasikan berbagai jenis manfaat konsumen sebagai utilitarian atau hedonis ( $\mathrm{Na}$ et al., 2007; Chitturi et al., 2008; Prayag et al., 2017). Anselmsson et al. (2007) mengemukakan bahwa adanya perbedaan merek mempunyai perbedaan pada manfaat utilitarian dan manfaat hedonis. Manfaat utilitarian relatif nyata dan berhubungan dengan efisiensi, utilitas, dan ekonomi. Manfaat utilitarian berkaitan dengan manfaat yang terkait dengan kepemilikan produk, mirip dengan teori orang ekonomi (Chen et al., 2005) dan persepsi menawarkan produk untuk memenuhi kebutuhan fungsional pelanggan (Na et al., 2007).
Sedangkan manfaat hedonis relatif tidak berwujud dan berhubungan dengan stimulasi intrinsik, kesenangan, dan kesenangan (Wang et al., 2017). Manfaat ini memanifestasikan nilai hiburan potensial dari suatu produk/layanan dan berasal dari kesenangan, kegembiraan, dan kenikmatan yang timbul dari pengalaman berbelanja (Carpenter dan Fairhurst, 2005; Wang et al., 2017). Dengan demikian, paket produk utilitarian membantu konsumen memaksimalkan kegunaan, kepuasan, pencapaian, dan kinerja pembelian mereka. Demikian pula, paket produk hedonis memberikan kesenangan, hiburan, kesenangan, kesenangan, dan kenikmatan.

Sebaliknya, fokus penelitian ini adalah pada interaksi antara dua dimensi ini dalam mempengaruhi konsekuensi emosional dan perilaku pasca-konsumsi, masalah yang perlu diselidiki lebih lanjut. Penelitian ini mengembangkan kerangka kerja konseptual peran yang dimainkan oleh manfaat hedonis dan utilitarian dalam membangkitkan berbagai tipe positif, seperti kepuasan konsumen pasca menggunakan produk yang mereka beli. Chitturi, et al. (2008) mengemukakan bahwa konsumsi manfaat hedonis superior yang ditawarkan oleh suatu produk membangkitkan emosi promosi yang lebih besar dari keceriaan dan kegembiraan. Sedangkan konsumsi manfaat utilitarian yang unggul membangkitkan emosi pencegahan rasa percaya diri dan keamanan yang lebih besar. Emosi promosi dan pencegahan ini adalah anteseden utama dari kepuasan pasca konsumsi yang masing-masing mengarah pada niat untuk menyampaikan kepada orang lain dan niat pembelian kembali yang lebih besar.

Istilah experience atau pengalaman sering digunakan untuk merujuk pada penawaran produk dalam pengaturan layanan yang melibatkan konsumsi hedonis (Ali et al., 2016). Beberapa peneliti mengonseptualisasikan pengalaman konsumen sebagai konstruk psikologis: respons holistik dan subyektif yang dihasilkan dari kontak pelanggan dengan penyedia layanan yang mungkin melibatkan kognisi dan pengaruh pelanggan (Ali et al., 2016; Altunel dan Erkut, 2015; Li et al., 2016). Mereka mengemukakan bahwa bagi penyedia layanan untuk bersaing, layanan mereka harus memuaskan dan menciptakan pengalaman pelanggan yang positif. Meyer dan Schwager (2007) mempresentasikan definisi pengalaman pelanggan (customer experience) adalah respons internal dan 
subyektif yang dimiliki pelanggan terhadap setiap kontak langsung atau tidak langsung dengan perusahaan. Kontak langsung umumnya terjadi dalam proses pembelian, penggunaan, dan layanan dan biasanya diprakarsai oleh pelanggan. Kontak tidak langsung paling sering melibatkan pertemuan yang tidak direncanakan dengan perwakilan produk, layanan, atau merek perusahaan dan mengambil bentuk rekomendasi atau kritik dari mulut ke mulut, iklan, laporan berita, ulasan, dan sebagainya.

Customer Experience merupakan pengalaman pelanggan sebelumnya melalui interaksi secara langsung maupun tidak langsung dengan perusahaan. Indikator pengalaman pelanggan dalam penelitian ini mengacu pada Schmitt (2010) yang meliputi: a) Sense, yaitu indra yang dimiliki oleh manusia sebagai alat untuk merasakan produk dan jasa yang ditawarkan, b) Feel, yaitu rasa yang ditampilkan melalui ide, kesenangan, dan reputasi akan pelayanan pelanggan, c) Think, yaitu pengalaman menuntut kecerdasan dengan tujuan menciptakan pengalaman kognitif dan pemecahan masalah dengan melibatkan pelanggan secara kreatif, d) Act, yaitu didesain untuk menciptakan pengalaman pelanggan yang berhubungan dengan tubuh secara fisik, e) Relate, yaitu adanya hubungan dengan orang lain, kelompok sosial lain (seperti pekerjaan, gaya hidup) atau identitas sosial yang lebih luas.

Pelanggan yang puas adalah tujuan akhir dari setiap bisnis, karena dampak potensial pada perilaku pembelian berulang (Ali et al., 2016; Kimet al., 2016). Definisi dan Konseptualisasi kepuasan pelanggan bervariasi di seluruh literatur pemasaran. Kepuasan adalah perasaan senang dan kecewa dari pelanggan yang dihasilkan dari membandingkan produk atau layanan dengan harapan mereka (Kotler dan Keller, 2016). Kepuasan konsumen merupakan faktor kunci yang mendorong ketika kinerja produk atau layanan melebihi harapan. Kepuasan konsumen secara keseluruhan terhadap produk atau layanan setelah beberapa kali melakukan pembelian dan pengalaman mereka dari waktu ke waktu akan mengarah pada loyalitas konsumen (Meesala dan Paul, 2016).

Kepuasan konsumen merupakan tingkat perbandingan atau hasil evaluasi konsumen atas pelayanan yang diberikan dengan harapannya menggunakan produk atau jasa perusahaan (Tjiptono, 2011:453). Kepuasan konsumen dalam penelitian ini, diukur melalui beberapa indikator yang mengacu pada: 1) Overall Satisfaction, secara keseluruhan puas terhadap sebuah pengalaman tertentu dengan menggunakan produk ini. 2) Confirmation of Expectation, tidak menyesal tentang keputusan untuk menggunakan produk ini. 3) Comparison to Ideal, puas dengan hasil yang diperoleh setelah menggunakan produk ini. Kepuasan konsumen merupakan prediktor yang kuat dalam menjelaskan niat konsumen untuk merekomendasikan kepada orang lain dan berdampak pada perilaku rekomendasi. Sedangkan manfaat hedonis yang diperoleh dari menggunakan produk adalah anteseden langsung dari niat untuk merekomendasikan tetapi manfaat utilitarian memiliki efek tidak langsung pada niat untuk merekomendasikan melalui kepuasan (Xu et al., 2015).

Niat untuk merekomendasikan (intention to recommended) mengandung perbedaan yang jelas dengan word of mouth (de Matos, 2008). WOM memiliki dua dimensi (de Matos, 2008) dimensi pertama disebut sebagai kegiatan WOM (WOM activities) yang membahas frekuensi komunikasi WOM, jumlah orang yang dipengaruhi, dan informasi yang diberikan oleh Pemrakarsa WOM. Dimensi kedua disebut sebagai WOM pujian (WOM valence) yang mencerminkan komunikasi valensi yang dapat bersifat positif, netral dan negatif. Hal ini berarti bahwa niat konsumen untuk merekomendasikan kepada orang lain dapat bersifat positif ataupun negatif berdasarpak dari pengalaman dan apa yang mereka rasakan. Dengan demikian, rekomendasi berbeda dari kegiatan WOM dalam hal itu mewakili valensi positif WOM sedangkan Kegiatan WOM mungkin melibatkan penyebaran informasi negatif suatu produk (Prayag et al., 2015).

Penelitian ini mengonseptualisasikan rekomendasi sebagai sejauh mana seseorang mengatakan halhal positif tentang suatu produk dan mendorong orang lain untuk menggunakan produk. Beberapa studi terdahulu (Prayag et al., 2015; Xu et al., 2015) mengemukakan bahwa konsumen yang merasa puas terhadap penggunaan suatu produk tertentu akan menyebabkan mereka untuk memberikan rekomendasi kepada orang lain untuk menggunakan produk yang serupa, sebaliknya apabila konsumen merasa tidak puas maka mereka akan menjelek-jelekan produk tersebut.

Berdasarkan latar belakang dan kajian literatur diatas, maka kerangka konseptual yang digunakan dalam penelitian ini adalah sebagai berikut: 


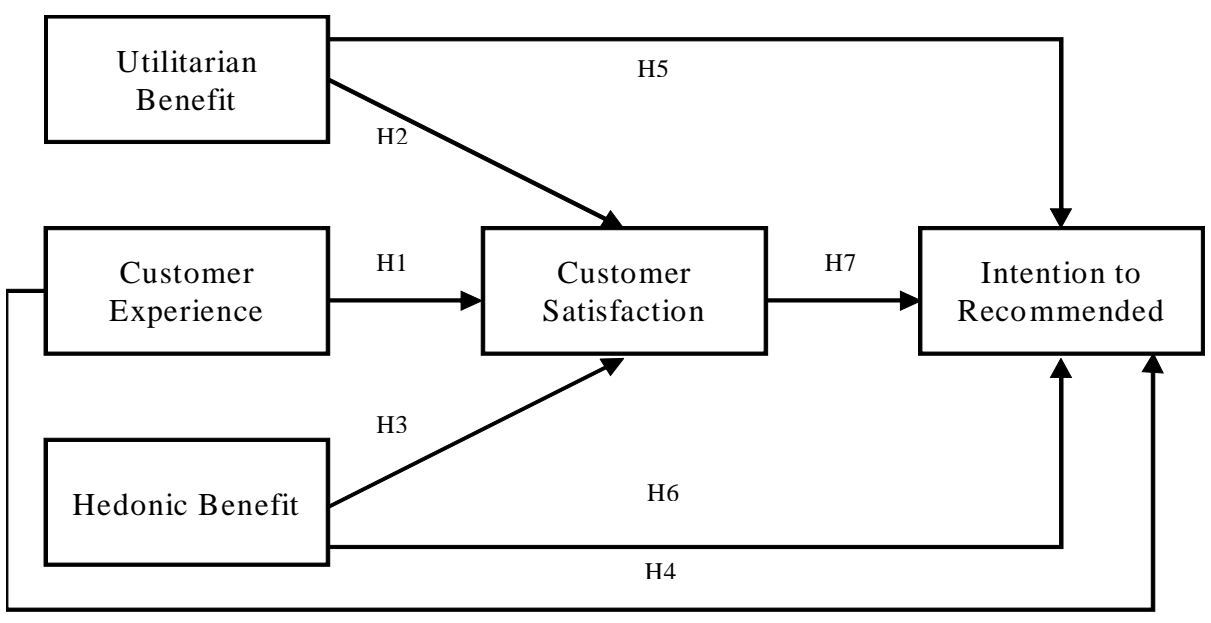

Gambar 1: Kerangka Konseptual

Hipotesis:

$\mathrm{H}_{1}$ : Terdapat pengaruh variabel customer experience terhadap customer satisfaction pada konsumen iPhone di Kebumen.

$\mathrm{H}_{2}$ : Terdapat pengaruh variabel utilitarian benefit terhadap customer satisfaction pada konsumen iPhone di Kebumen.

$\mathrm{H}_{3}$ : Terdapat pengaruh variabel hedonic benefit terhadap customer satisfaction pada konsumen iPhone di Kebumen.

$\mathrm{H}_{4}$ : Terdapat pengaruh variabel customer experience terhadap intention to recommended pada konsumen iPhone di Kebumen.

$\mathrm{H}_{5}$ : Terdapat pengaruh variabel utilitarian benefit terhadap intention to recommended pada konsumen iPhone di Kebumen.

$\mathrm{H}_{6}$ : Terdapat pengaruh variabel hedonic benefit terhadap intention to recommended pada konsumen iPhone di Kebumen.

$\mathrm{H}_{7}$ : Terdapat pengaruh variabel customer satisfaction terhadap intention to recommended pada konsumen iPhone di Kebumen.

\section{METODOLOGI PENELITIAN}

Metode penelitian yang digunakan dalam mengumpulkan data adalah dengan metode survey, yaitu dengan metode kuesioner (angket), dimana metode ini digunakan untuk memperoleh data dengan mengajukan seperangkat pertanyaan atau peryataan tertulis kepada responden. Skala pengukuran yang digunakan dalam penelitian ini menggunakan model skala likert 5 point (Hair et al., 1998) yaitu: sangat setuju (SS) memperoleh skor 5, setuju (S) memperoleh skor 4, netral (N) memperoleh skor 3, tidak setuju (TS) memperoleh skor 2, dan sangat tidak setuju (STS) memperoleh skor 1 . Teknik pengumpulan data dalam penelitian ini dengan cara pengamatan, wawancara, penyebaran kuesioner (Sugiyono, 2010:402).

Populasi yang akan digunakan sebagai penelitian ini adalah konsumen iPhone di Kota Kebumen. Lokasi penelitian Kota Kebumen karena merupakan pusat kota dari Kabupaten Kebumen. Sampel dalam penelitian ini melibatkan 100 responden yang menggunakan iPhone dengan menggunakan purposive sampling sebagai tehnik pengambilan sampel.

Uji validitas digunakan untuk mengukur sah atau valid tidaknya suatu kuesioner (Ghozali, 2011). Suatu kuesioner dikatakan valid (sah) jika pertanyaan di dalam kuesioner tersebut mampu mengungkapkan sesuatu yang akan diukur. Uji validitas adalah suatu ukuran yang menunjukan kevalidan atau keaslian suatu instrument. Tinggi rendahnya validitas instrument menunjukan sejauh mana data yang terkumpul tidak menyimpang dari gambaran tentang variabel yang dimaksudkan. Hasil uji validitas akan didapat dari hasil corrected item total correlation. Berdasarkan dengan ketentuan bahwa alat ukur atau item butir kuesioner dinyatakan valid apabila nilai corrected item total correlation lebih besar bila dibandingkan dengan $r$ tabel dengan tingkat signifikan lebih kecil dari 0,05 dengan dasar pengambilan keputusan (Ghozali, 2011:52).

Reliabilitas adalah indeks yang menunjukan sejauh mana suatu hasil relatif konsisten apabila pengukuran diulangi dua kali atau lebih. Angket dikatakan reliabel (andal) jika jawaban respon terhadap pertanyaan adalah konsisten atau stabil dari waktu ke waktu. Untuk mengukur reliabilitas digunakan nilai Cronbach's alpha. Realibilitas suatu 
konstruk variabel dikatakan baik jika memiliki nilai Cronbach's Alpha > dari 0,7 dan apabila nilai Cronbach's Alpha < dari 0,7 maka hal ini mengindikasikan ada beberapa responden yang menjawab tidak konsisten atau variabel tersebut dinyatakan tidak reliabel (Ghozali, 2011: 47).

Analisis jalur (path analysis) menurut Sugiyono (2010:297) merupakan pengembangan dari analisis regresi, sehingga analisis regresi dapat dikatakan sebagai bentuk khusus dari analisis jalur. Path Analysis digunakan apabila secara teori kita yakin berhadapan dengan masalah yang berhubungan sebab akibat (Abdurrahman et al., 2011: 235). Tujuan analisis ini adalah menerangkan akibat langsung (direct effect) dan tidak langsung (indirect affect) seperangkat variabel, sebagai variabel penyebab, terhadap variabel lainnya yang merupakan variabel akibat.

Uji parsial (uji t) menurut Ghozali (2011:11) digunakan untuk menunjukan seberapa jauh pengaruh variabel penjelas/independen secara individual menerangkan variabel dependen. Hipotesis statistic dalam penelitian ini ditentukan sebagai berikut: Jika nilai $\mathrm{t}$ hitung $>\mathrm{t}$ tabel, maka hipotesis diterima, dan jika nilai t hitung < t tabel, maka hipotesis ditolak.
Selain uji hipotesis, dalam penelitian ini juga akan di uji pada koefisien determinasi $\left(\mathrm{R}^{2}\right)$ menurut Ghozali (2011:97) adalah untuk mengukur seberapa jauh kemampuan model dalam menerangkan variasi variabel dependen. Koefisien determinasi memiliki kelemahan yaitu bias terhadap jumlah variabel bebas yang dimasukan dalam model regresi, dimana setiap penambahan satu variabel bebas dan pengamatan dalam model akan meningkatkan nilai $\mathrm{R}^{2}$ meskipun variabel yang dimasukan itu tidak memiliki pengaruh yang signifikan terhadap variabel dependen. Penelitian ini maka menggunakan koefisien determinasi yang telah disesuaikan (Adjusted $R$ Square) untuk mengurangi kelemahan tersebut.

\section{HASIL DAN PEMBAHASAN}

Alat analisis yang digunakan dalam model ini dengan menggunakan bantuan program SPSS 24.0 for windows. Berdasarkan data yang sudah dikumpulkan langkah selanjutnya adalah menampilkan analisis dan membahas uji statistik yaitu, uji validitas dan reliabilitas, analisis jalur, dan uji hipotesis.

Hasil uji validitas dan reliabilitas dari pada setiap pernyataan dan variabel yang sudah diolah dapat dilihat pada Tabel 1 .

Tabel 1. Hasil Uji Validitas

\begin{tabular}{|c|c|c|c|c|}
\hline Variabel & Item & r hitung & $\mathrm{r}$ tabel & Keterangan \\
\hline \multirow{5}{*}{ Customer Experience } & CE1 & 0.677 & \multirow{5}{*}{0.196} & \multirow{5}{*}{ Valid } \\
\hline & CE2 & 0.661 & & \\
\hline & CE3 & 0.651 & & \\
\hline & CE4 & 0.704 & & \\
\hline & CE5 & 0.526 & & \\
\hline \multirow{4}{*}{ Utilitarian Benefit } & UB1 & 0.648 & \multirow{4}{*}{0.196} & \multirow{4}{*}{ Valid } \\
\hline & UB2 & 0.705 & & \\
\hline & UB3 & 0.732 & & \\
\hline & UB4 & 0.788 & & \\
\hline \multirow{4}{*}{ Hedonic Benefit } & HB1 & 0.679 & \multirow{4}{*}{0.196} & \multirow{5}{*}{ Valic } \\
\hline & HB2 & 0.666 & & \\
\hline & HB3 & 0.674 & & \\
\hline & HB4 & 0.682 & & \\
\hline \multirow{3}{*}{ Customer Satisfaction } & CS1 & 0.740 & \multirow{4}{*}{0.196} & \\
\hline & $\mathrm{CS} 2$ & 0.745 & & \multirow[t]{3}{*}{ Valic } \\
\hline & $\mathrm{CS} 3$ & 0.706 & & \\
\hline \multirow{3}{*}{ Intention to Recommended } & IR1 & 0.684 & & \\
\hline & IR2 & 0.677 & \multirow[t]{2}{*}{0.196} & \multirow[t]{2}{*}{ Valid } \\
\hline & IR3 & 0.748 & & \\
\hline
\end{tabular}

Sumber: Data diolah, 2018

Berdasarkan hasil uji validitas diatas menunjukkan besarnya nilai hitung pada setiap item pernyataan lebih besar dari besarnya $r$-tabel (0.196). Maka dari itu dapat disimpulkan bahwa semua butir pernyataan dalam kuesioner yang berjumlah 19 item dinyatakan valid dan dapat digunakan dalam penelitian ini. Hal ini sudah sesuai dengan kaidah dasar penelitian (Sugiyono, 2010). 
Tabel 2. Hasil Uji Reliabilitas

\begin{tabular}{llll}
\hline Variabel & Cronbach alpha & Batas Penerimaan & Keterangan \\
\hline Customer Experience & 0.790 & 0.7 & Reliabel \\
Utilitarian Benefit & 0.747 & 0.7 & Reliabel \\
Hedonic Benefit & 0.744 & 0.7 & Reliabel \\
Customer Satisfaction & 0.801 & 0.7 & Reliabel \\
Intention to Recommended & 0.726 & 0.7 & Reliabel \\
\hline
\end{tabular}

Sumber: Data diolah, 2018

Reliabilitas dalam penelitian ini diuji dengan menggunakan uji Cronbach Alpha, dengan ketentuan apabila nilai Cronbach Alpha $>0.7$ maka instrumen pengukuran reliabel. Berdasarkan hasil uji reliabilitas di atas dapat diambil kesimpulan bahwa semua variabel sudah melebihi batas standar penerimaan, maka dari itu semua variabel dalam penelitian ini dinyatakan valid.

Analisis data yang digunakan untuk menguji jalur dan hipotesis dalam kerangka penelitian adalah ini dengan menggunakan bantuan program SPSS 24.0. Berikut adalah hasil uji analisis jalur dan uji hipotesis.

Tabel 3. Hasil Uji Analisis Jalur dan Uji Hipotesis

\begin{tabular}{ccccccc}
\hline Hipotesis & & Path & & $\begin{array}{c}\text { Standardized } \\
\text { coefficients }\end{array}$ & $t$-value & Hasil \\
\hline H1 & CE & $\rightarrow$ & CS & 0.213 & 2.257 & Diterima \\
H2 & UB & $\rightarrow$ & CS & 0.241 & 2.655 & Diterima \\
H3 & HB & $\rightarrow$ & CS & 0.306 & 3.207 & Diterima \\
H4 & CE & $\rightarrow$ & IR & 0.185 & 2.275 & Diterima \\
H5 & UB & $\rightarrow$ & IR & 0.068 & 0.982 & Ditolak \\
H6 & HB & $\rightarrow$ & IR & 0.214 & 2.538 & Diterima \\
H7 & CS & $\rightarrow$ & IR & 0.351 & 4.099 & Diterima \\
\hline
\end{tabular}

Sumber: Data diolah, 2018

Analisis jalur pada penelitian ini diuji dengan menggunakan dua persamaan jalur yaitu persamaan jalur I dan persamaan jalur II serta diuji pembuktian hipotesisnya. Pada persamaan jalur I, peneliti menguji hubungan dan pengaruh variabel customer experience (CE), utilitarian benefit (UB), dan hedonic benefit $(\mathrm{HB})$ terhadap variabel customer satisfaction (CS). Berdasarkan hasil olah data yang dituangkan dalam tabel 3 diatas, maka dapat dibuat persamaan jalur I adalah sebagai berikut: $\mathrm{Y} 1=$ $0.213 \mathrm{X} 1+0.241 \mathrm{X} 2+0.306 \mathrm{X} 3+€ 1$.

Berdasarkan persamaan pada jalur I dan tabel 3 diatas, maka dapat dijelaskan bahwa hubungan antara variabel customer experience (CE) dengan variabel customer satisfaction (CS) adalah positif yang memiliki pengaruh sebesar 0.213 atau 21.3 persen. sedangkan untuk uji hipotesis dinyatakan bahwa $\mathrm{H} 1$ diterima, hal ini didukung oleh besarnya nilai $t$-hitung lebih dari nilai $t$-tabel yaitu $2.257>$ 1.985. Hasil penelitian ini sejalan dengan studi sebelumnya (Ali, et al., 2016; Altunel dan Erkut, 2015) yang mengemukakan bahwa costumer experience sebagai predictor dari kepuasan konsumen. Hal ini berarti bahwa konsumen yang memiliki pengalaman yang positif terhadap produk iPhone seperti, pengalaman pada saat menggunakan fitur, atribut, kemudahan dan lain sebagainya akan berdampak pada kepuasan mereka. Artinya semakin baik pengalaman yang mereka alami akan dapat meningkatkan kepuasan mereka.

Pengujian hipotesis kedua $\left(\mathrm{H}_{2}\right)$ terbukti diterima, hal ini berdasarkan nilai t-hitung yang lebih besar dari nilai t-tabel yaitu $2.655>1.985$. Sedangkan hubungan dan besarnya pengaruh antara variabel utilitarian benefit (UB) dan customer satisfaction (CS) adalah positif dan pengaruhnya sebesar 0.241 atau 24.1 persen. Hasil penelitian ini sejalan dengan yang dilakukan Kesari dan Atulkar (2016); Wang et al. (2017) yang menyatakan bahwa utilitarian benefit dapat berpengaruh positif terhadap kepuasan konsumen. Hal ini tentunya mempunyai makna bahwa manfaat kegunaan, seperti manfaat inti (utama) dan tambahan yang ada pada produk iPhone terbukti dapat mempengaruhi kepuasan konsumen. Hal ini berarti bahwa semakin iPhone memiliki manfaat kegunaan yang baik maka kepuasan konsumen akan semakin meningkat.

Pada hipotesis ketiga $\left(\mathrm{H}_{3}\right)$ hasil pengujian dinyatakan diterima, hal ini dibuktikan dengan besarnya nilai t-hitung yang lebih besar dari nilai ttabel yaitu $3.207>1.985$. Sedangkan untuk hubungan dan besarnya pengaruh antara variabel 
hedonic benefit (HB) dengan customer satisfaction (CS) adalah positif dengan besarnya pengaruh 0.306 atau 30.6 persen. Studi ini didukung oleh studi sebelumnya yang dilakukan oleh Kesari dan Atulkar (2016); Wang et al, (2017) yang menyatakan bahwa hedonic benefit dapat berpengaruh positif terhadap kepuasan konsumen. Hal ini berarti bahwa manfaat hedonis dari produk iPhone mampu membuat dan mempengaruhi konsumen merasa puas, semakin tinggi produk iphone dapat memberikan manfaat hedonis seperti gaya hidup, kemewahan produk dan lain sebagainya maka kepuasan konsumen akan semakin meningkat.

Pengujian hubungan dan pengaruh serta pengujian $\mathrm{H}_{4}-\mathrm{H}_{7}$ yang berada pada persamaan jalur II yang digunakan untuk menguji hubungan dan pengaruh langsung dan tidak langsung pada model empiris dalam penelitian ini. Adapun persamaan pada structural jalur kedua adalah sebagai berikut: Y2 = $0.185 X 1+0.68 X 2+0.214 X 3+0.351 Y 1+€ 2$.

Pada hipotesis keempat $(\mathrm{H} 4)$ menguji hubungan dan pengaruh antara variabel customer experience (CE) terhadap variabel intention to recommended (IR). Hasil menunjukkan bahwa uji hipotesis dinyatakan diterima, hal ini didukung oleh besarnya nilai t-hitung lebih dari nilai t-tabel $(2.275>1.985)$. Sedangkan untuk besar pengaruhnya adalah 0.185 atau 18.5 persen. Hasil penelitian ini didukung oleh temuan penelitian sebelumnya yang dilakukan oleh Altunel dan Erkut (2015) yang menyatakan bahwa customer experience akan memberikan dampak yang positif terhadap niat konsumen untuk merekomendasikan kepada orang lain. Dengan demikian berarti bahwa pengalaman konsumen yang semakin berkesan dan positif terhadap iPhone akan mampu mempengaruhi niat konsumen untuk merekomendasikan kepada orang lain.

Berbeda dengan hasil pengujian hipotesis kelima $\left(\mathrm{H}_{5}\right)$ yang menguji hubungan antara variabel utilitarian benefit (UB) terhadap variabel intention to recommended (IR) yang dinyatakan ditolak karena besarnya nilai t-hitung lebih kecil dari t-tabel $(0.982<1.985)$ dan pengaruhnya hanya sebesar 0.068 atau 6.8 persen. Hal ini berarti bahwa manfaat kegunaan pada produk iPhone tidak mampu untuk membuat konsumen berniat untuk merekomendasikan kepada orang lain untuk menggukanan atau membeli iPhone. Hal ini sejalan dengan penelitian sebelumnya dimana konsumen merasa manfaat kegunaan antara produk smartphone memiliki kemiripan antara satu sama lain (Xu et al., 2015).
Pengujian hipotesis kedua $\left(\mathrm{H}_{6}\right)$ dinyatakan diterima, hal ini berdasarkan nilai t-hitung yang lebih besar dari nilai t-tabel yaitu $2.538>1.985$. Sedangkan hubungan dan besarnya pengaruh antara variabel hedonic benefit (HB) dan intention to recommended (IR) adalah positif dan pengaruhnya sebesar 0.214 atau 21.4 persen. Hasil penelitian ini sejalan dengan yang dilakukan oleh wang et al. (2017) yang menyatakan bahwa hedonic benefit dapat berfungsi sebagai anteseden dari niat konsumen untuk merekomendasikan kepada orang lain. Hal ini berarti bahwa semakin produk iPhone dapat memberikan manfaat hedonis maka frekuensi konsumen dalam niat untuk merekomendasikan produk iPhone kepada orang lain akan semakin meningkat.

Pengujian hipotesis ketujuh $\left(\mathrm{H}_{7}\right)$ terbukti diterima, hal ini berdasarkan nilai t-hitung yang lebih besar dari nilai t-tabel yaitu 4.099 > 1.985. Sedangkan hubungan dan besarnya pengaruh antara variabel utilitarian benefit (UB) dan customer satisfaction (CS) adalah positif dan pengaruhnya sebesar 0.351 atau 35.1 persen. Hasil studi ini didukung oleh studi sebelumnya yang dilakukan oleh Lee dan Kim (2019); Prayag et al. (2015) yang mengungkap bahwa kepuasan konsumen sebagai prediktor yang kuat dari niat untuk merekomendasikan kepada konsumen lain. Hal ini berarti bahwa konsumen yang puas pada produk iPhone akan meningkatkan niat mereka untuk merekomendasikan kepada orang lain.

\section{SIMPULAN}

Berdasarkan penelitian terdahulu manfaat desain dapat dibedakan menjadi dua yaitu, manfaat utilitarian dan manfaat hedonis. Hasil penelitian ini menunjukkan bahwa dari ketujuh hipotesis yang diajukan terdapat enam hipotesis yang diterima dan satu hipotesis yang ditolak yaitu hipotesis kelima. Temuan dari penelitian dapat memberikan kontribusi bahwa kepuasan konsumen pada iPhone dapat meningkatkan niat konsumen untuk memberikan rekomendasi kepada konsumen yang lain untuk membeli atau menggunakan iPhone.

Hasil penelitian menunjukkan bahwa diantara manfaat hedonis dan manfaat utilitarian, terbukti bahwa konsumen akan merasa puas dengan manfaat desain iPhone. Manfaat hedonis akan dapat meningkatkan kepuasan konsumen serta menumbuhkan niat mereka untuk merekomendasikan kepada orang lain, tidak untuk manfaat utilitarian yang hanya 
berdampak pada kepuasan konsumen tetapi mereka tidak ada niat untuk memberikan rekomendasi kepada orang lain. Hasil temuan lain menunjukkan bahwa pengalaman konsumen (consumer experience) menggunakan iPhone terbukti dapat membuat konsumen merasa puas dan dapat menumbuhkan niat untuk merekomendasikan. Studi ini memiliki beberapa keterbatasan antara lain sample size yang kecil dan area penelitian yang sempit. Untuk studi kedepannya diharapkan dapat memperluas dan memperbesar ukuran sample penelitian.

\section{REFERENSI}

Abdurrahman, Maman., Simbas Ali Muhidin dan Ating Somantri. 2011. Dasar-Dasar Metodologi Statistik untuk penelitian. Bandung: Pusaka Setia.

Ali, Faizan., Woo Gon Kim, Jun Li \& Hyeon-Mo Jeon. 2016. Make it Delightful: Customers' Experience, Satisfaction and Loyalty in Malaysian Theme Parks. Journal of Destination Marketing \& Management. http://dx.doi.org/10. 1016/j.jdmm.2016.05.003.

Altunel, M. C., \& Erkut, B. 2015. Cultural Tourism in Istanbul: The Mediation Effect of Tourist Experience and Satisfaction on the Relationship Between Involvement and Recommendation Intention. Journal of Destination Marketing \& Management, Vol. 4, 213-221.

Ampuero, O., \& Vila, N. 2006. Consumer Perceptions of Product Packaging. Journal of Consumer Marketing, Vol. 23, 100-112.

Anselmsson, J., Johansson, U., \& Persson, N. 2007. Understanding Price Premium for Grocery Products: A Conceptual Model of CustomerBased Brand Equity. Journal of Product and Brand Management, 16, 401-414.

Apple. 2017. Apple annual report 2017. Washington, D.C.: Apple.

Carpenter, J. M., \& Fairhurst, A. 2005. Consumer Shopping Value, Satisfaction, and Loyalty for Retail Apparel Brands. Journal of Fashion Marketing and Management, 9, 256-269.

Chitturi, Ravindra, Rajagopal Raghunathan, and Vijay Mahajan. 2007. Form Versus Function: How the Intensities of Specific Emotions Evoked in Functional Versus Hedonic TradeOffs Mediate Product Preferences. Journal of Marketing Research, Vol. 44, 702-714.
Chitturi, Ravindra., Rajagopal Raghunathan, \& Vijay Mahajan. 2008. Delight by Design: The Role of Hedonic Versus Utilitarian Benefits. Journal of Marketing, Vol. 72, pp. 48-63.

Chen, T. Y., Chang, P. L., \& Chang, H. S. 2005. Price, Brand Cues, and Banking Customer Value. International Journal of Bank Marketing, Vol. 23, 273-291.

De Matos, C.A. and C.A.V. Rossi. 2008. Word-ofmouth Communications in Marketing: A MetaAnalytic Review of the Antecedents and Moderators. Journal of the Academy of Marketing Science, Vol. 36(4): p. 578-596.

Dewi, Putu Sundari Aprelia \& Suprapti, Ni Wayan Sri. 2018. Membangun Loyalitas Pelanggan Melalui Kepuasan Yang Dipengaruhi Oleh Kualitas Produk, Persepsi Harga Dan Citra Merek (Studi Pada Produk Smartphone Merek Oppo). Matrik: Jurnal Manajemen, Strategi Bisnis dan Kewirausahaan Vol. 12, No. 2. Doi: https://doi.org/10.24843/MATRIK: JMBK. 2018.v12.i02.p01

Fischer, A. R. H., \& Frewer, L. J. 2009. Consumer Familiarity with Foods and the Perception of Risks and Benefits. Food Quality and Preference, Vol. 20, 576-585.

Ghozali, Imam. 2011. Aplikasi Analisis Multivariate Dengan Program SPSS. Edisi II. Badan Penerbit: Universitas Diponegoro. Semarang.

Hair, J. R.., Anderson, R. E., Tatham, R. L., \& Black, W. C. 1998. Multivariate Data Analysis (5th ed.). Upper Saddle River, NJ: Prentice Hall.

Jang, N., Dickerson, K. G., \& Hawley, J. M. 2005. Apparel Product Development: Measures of Apparel Product Success and Failure. Journal of Fashion Marketing and Management, Vol. 9, 195-206.

Kesari, Bikrant \& Atulkar, Sunil. 2016. Satisfaction of mall shoppers: A study on perceived utilitarian and hedonic shopping values. Journal of Retailing and Consumer Services 31, pp. 2231.

Kim, W. G., Li, J. J., \& Brymer, R. A. 2016. The Impact of Social Media Reviews on Restaurant Performance: The Moderating role of excellence award. International Journal of Hospitality Management, 55(5), 41-51.

Kotler, P. \& Keller, K. L. (2016). Marketing Management. (15 ${ }^{\text {th }}$ ed). Pearson Education, Inc.

Krystallis, A., \& Ness, M. 2003. Motivational and Cognitive Structures of Greek Consumers in 
the Purchase of Quality Food Products. Journal of International Consumer Marketing, 16 (2), 7-36.

Lee, Young-Hee \& Kim, Ryang-Hee. 2019. Estimation of the Smartphone User' Satisfaction and Customer Intention on the Social Networking Service. 10.1007/978-3-319-949475_26.

Li, J. J., Kim, W. G., \& Wong, I. A. 2016. Does Destination Perception Differ Based on Traveler Type? A case of 'Las Vegas of Asia'. Tourism Planning \& Development. http:// dx.doi.org/10.1080/21568316.2016.1152289.

Löfgren, M. 2008. Customer Satisfaction in the First and Second Moments of Truth. Journal of Product and Brand Management, 17, 463-474.

Löfgren, M., \& Witell, L. 2005. Kano's Theory of Attractive Quality and Packaging. Quality Management Journal, 12(3), 7-30.

Meesala, Appalayya \& Paul, Justin. 2016. Service quality, consumer satisfaction and loyalty in hospitals: Thinking for the future. Journal of Retailing and Consumer Services. http:// dx.doi.org/10.1016/j.jretconser.2016.10.011.

Meyer, C., \& Schwager, A. 2007. Understanding Customer Experience. Harvard Business Review, 85(2), 117-126.

Na, W., Son, Y., \& Marshall, R. 2007. Why Buy Second-Best? The Behavioral Dynamics of Market Leadership. Journal of Product and Brand Management, 16, 16-22.

Orth, U. R., Campana, D., \& Malkewitz, K. 2010. Formation of Consumer Price Expectation Based on Package Design: Attractive and Quality Routes. Journal of Marketing Theory and Practice, 18, 23-40.

Prayag, Girish., Sameer Hosany, Birgit Muskat and Giacomo Del Chiappa. 2017. Understanding the Relationships Between Tourists' Emotional
Experiences, Perceived Overall Image, Satisfaction, and Intention to Recommend. Journal of Travel Research, Vol. 56(1) 41 -54.

Rundh, B. 2009. Packaging Design: Creating Competitive Advantage with Product packaging. British Food Journal, 111, 988-1002.

Silayoi, P., \& Speece, M. 2007. The Importance of Packaging Attributes: A Conjoint Analysis Approach. European Journal of Marketing, 41, 1495-1517.

Schmitt, B.H. 2010. Customer Experience Management: A Revolutionary Approach to Connecting with Your Customers, John Wiley \& Sons.

Smith, R. E., \& Wright, W. F. 2004. Determinants of Customer Loyalty and Financial Performance. Journal of Management Accounting Research, 16, 183-205.

Sugiyono. 2010. Metodologi Penelitian Bisnis: Pendekatan Kuantitatif, Kualitatif, dan R\&D. Bandung: Alfabeta.

Tjiptono, Fandy. 2011. Pemasaran Jasa. Malang: Penerbit Bayumedia.

Underwood, R. L. 2003. The Communicative Power of Product Packaging: Creating Brand Identity Via Lived and Mediated Experience. Journal of Marketing Theory and Practice, 11, 62-76.

Wang, Edward Shih-Tse. 2017. Different Effects of Utilitarian and Hedonic Benefits of Retail Food Packaging on Perceived Product Quality and Purchase Intention. Journal of Food Products Marketing, 23:3, 239-250, DOI: 10.1080/10454446.2014.885867.

Xu, Chenyan., Daniel Peak \& Victor Prybutok. 2015. A Customer Value, Satisfaction, and Loyalty Perspective of Mobile Application Recommendations, Decision Support Systems. Doi: 10.1016/j.dss.2015. 08.008. 